\title{
A Case of Frostbite or "It takes more than two pairs of socks to keep your feet warm"
}

\author{
Lt Col J R Brown, \\ MB, MSc, MFOM, RAMC, SO1 Med (Prev) \\ *Headquarters, Ist British Corps BFPO 39
}

SUMMARY: During February 1985 a squadron of an engineer regiment deployed into the field to exercise its men⿳⺈冂:

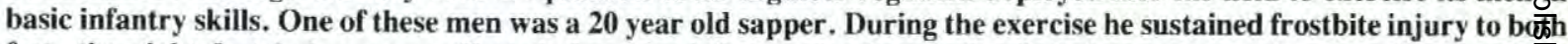
feet, the right foot being more affected than the left. The background, clinical progress and preventive medici雨e implications are discussed.

\section{Introduction}

On the morning of 10 Feb 85 a squadron of an amphibious engineer regiment based in BAOR deployed into the field to exercise its men in basic infantry skills. One of their number was a 20 year old sapper. Five centimetres of snow, drifted by a 7 knot wind to $13 \mathrm{cms}$, lay on the ground. The temperature at midday on $10 \mathrm{Feb}$ was $-2.6^{\circ} \mathrm{C}$, but fell steadily over the next 24 hours reaching $-7.5^{\circ} \mathrm{C}$ at $0001 \mathrm{hrs}$ and $-14.8^{\circ} \mathrm{C}$ at 0630 hrs on 11 Feb. By midday 11 Feb it rose only to $-7.3^{\circ} \mathrm{C}$. Snow flurries occurred as the wind speed rose to 13 knots. By 0001 hrs $12 \mathrm{Feb}$ the temperature was $-12.6^{\circ} \mathrm{C}$, reaching $-13.4^{\circ} \mathrm{C}$ at $0200 \mathrm{hrs}$ and the wind speed had freshened further to 15 knots. This final temperature, when wind chill is considered, is equivalent to a temperature of $-36^{\circ} \mathrm{C}$.

During the course of 11 Feb the young sapper complained of very painful feet, so much so that he reported this to his section commander. The section commander told him to "have a look at his feet", so he duly removed his high combat boots (which had been well broken in) and one pair of civilian pattern long thermal socks. He also had on a pair of Army issue polyester socks. As these were dry and unstained he did not remove them to inspect his feet but started to put his socks and boots back on again. He managed to put his right sock and boot on, and to lace it up tightly. However, as he drew on his left boot a section attack was made on his position. He was unable to do more than tie the lace round the left boot, neither tightening the boot up, nor lacing it through the top three holes. He did not adjust his laces further before the boot was taken off.

For the rest of the day his feet continued to be painful occasionally, but at other times they were numb causing him some awkwardness of gait.

The following night, whilst lying in a sleeping bag under a poncho without underbody insulation, he could tolerate the pain no longer. He was casevaced to his local medical centre and bedded down for the rest of the night. At that time the distal parts of his feet were waxy white. No active measures were taken to warm his feet. By 0600 hrs they had become extremely painful and purple. Shortly afterwards he was transferred to BMH Rinteln.

\section{Clinical}

On arrival in hospital, it was apparent that this young soldier had suffered a considerable degree of frostbies. He was given expectant care in the form of bed rest wig a foot cradle, analgesia and antibiotic therapy to avgid secondary infection. Sixteen days later, he wक् transferred to QEMH Woolwich as lines of demarcatign had by then become established on both feet (Fig $1 \&$ M . His left foot recovered well with minor tissue loss on but his right foot eventually needed to have five toos amputated at the metatarsophalangeal joints (Fig Although his left foot remains physically inta $\mathrm{F}_{\mathrm{it}}$ exhibits a marked response to minor cold challenge $\overrightarrow{\AA^{t}}$ ith prolonged vasospasm as assessed by thermography. $\frac{\text { ? }}{\mathrm{D}} \mathrm{Ts}$ indicates that he will now be very susceptible to fuarter cold injury. He has required seven months of rehal $9 i \overrightarrow{0}$ tion. Full rehabilitation has been rendered more dif $\mathrm{g} c$ ạt by the soldier's own psychological reaction to the lesf part of his foot.

\section{Conclusion}

This case illustrates two important factors in prevention of cold injury. Firstly, it underlines the importance of daily and proper inspection of a mats feet. This might well have prevented any permant injury to this young man. Secondly, the need comfortable boots is illustrated. Causing boots to fit t tightly by tight lacing and the wearing of two pairs socks completely negates the value of thermal soc. This young man's left foot escaped because of the charfige accident of a section attack!

In physical terms this soldier has not lost much tissige or ambulatory function. However, he has sufferd considerable disability in that many types of employment - not just the services - will be wholly a partially closed to him. Susceptibility to cold injury $\Phi_{0}$ this degree would be a handicap in many jobs entailimg outdoor work, for example farming and working on Bil rigs. Apart from the relatively short term psychologia stress this young man has suffered, this incident may weी। have a profound effect on his whole life.

In recent years the army has increased its trainio g during the harsh winter months of January ad February. Even during the second half of Novemaer 


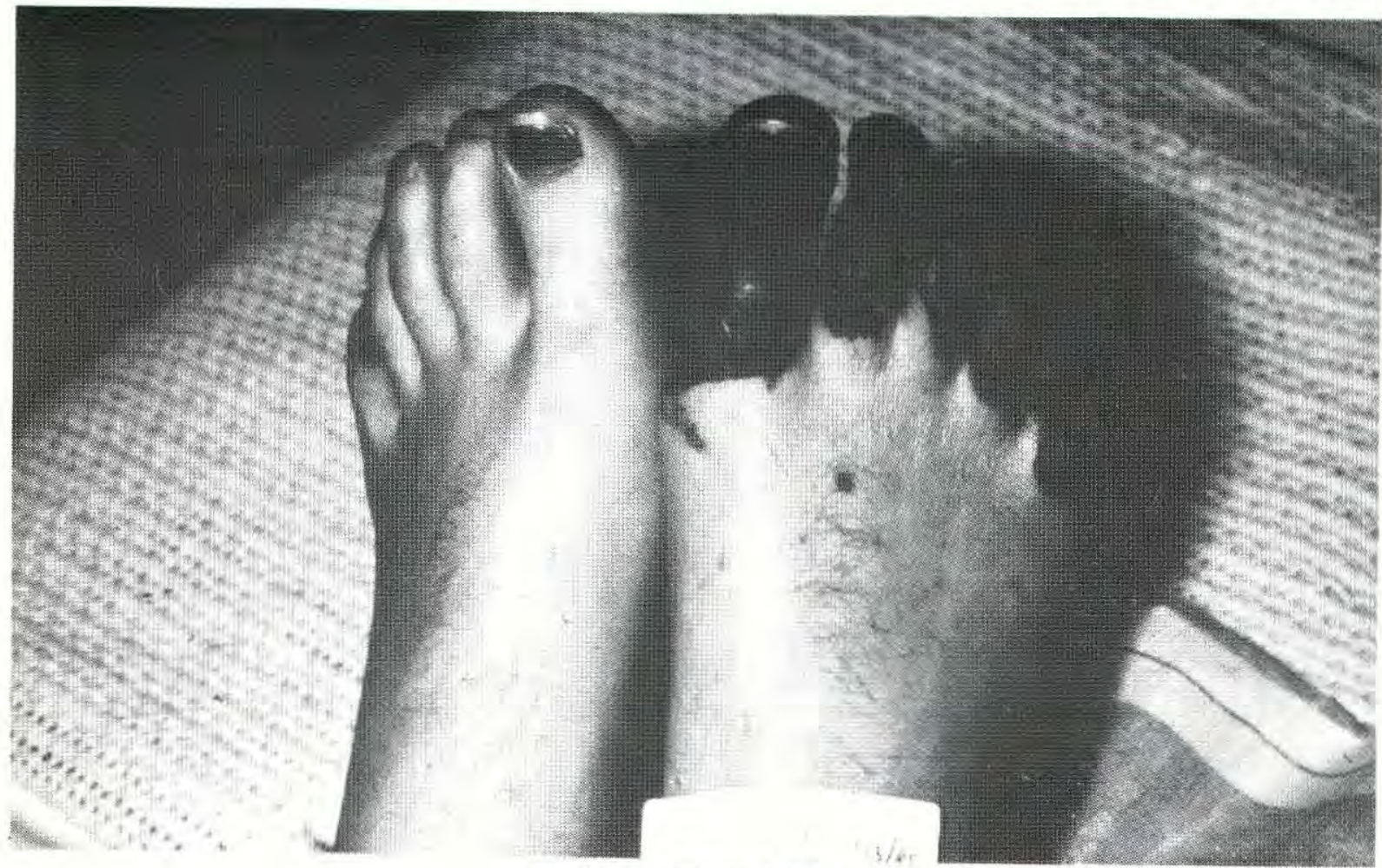

Fig. 1. Appearance at 21 days.

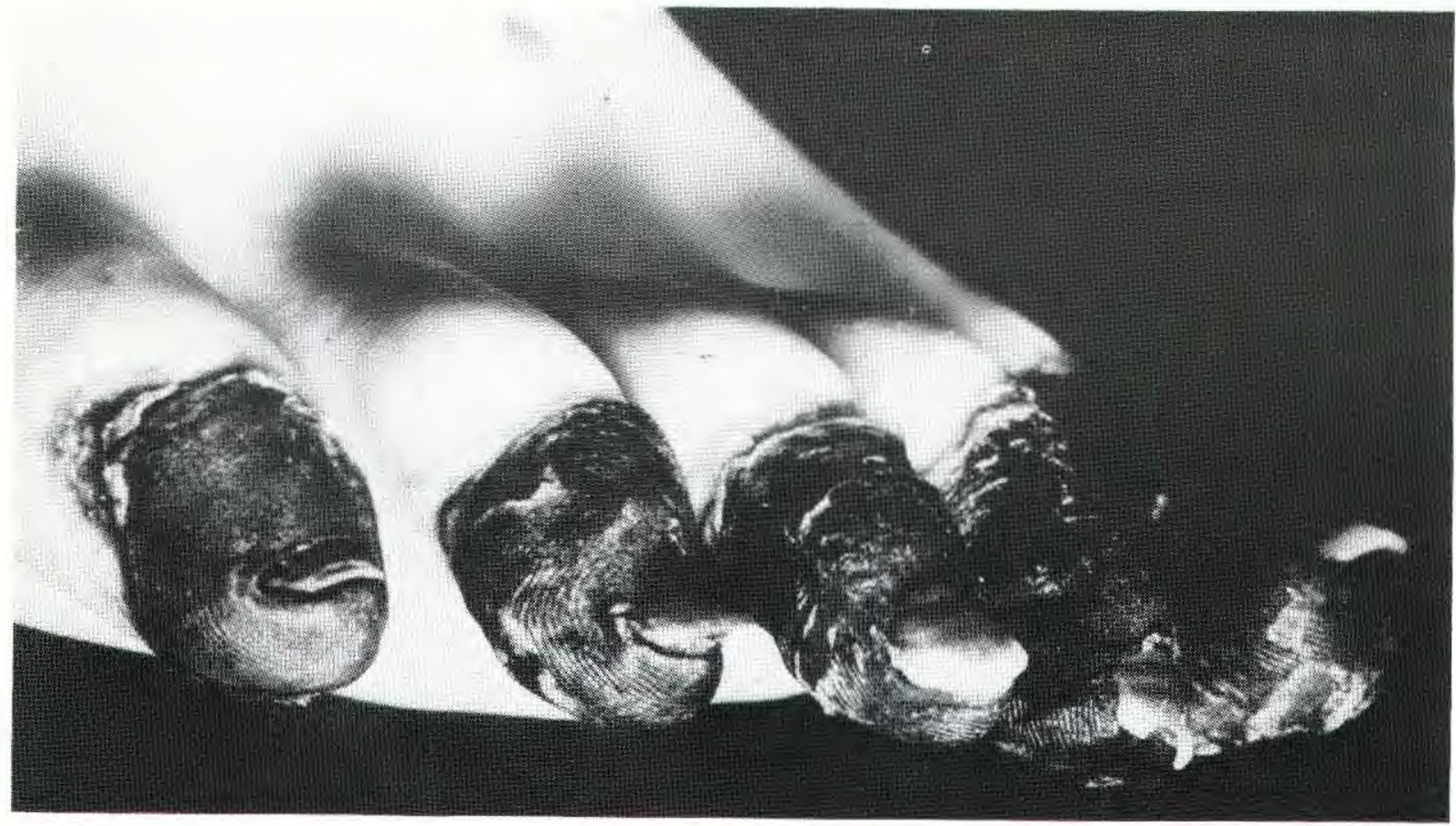

Fig. 2. Right foot prior to surgery. 


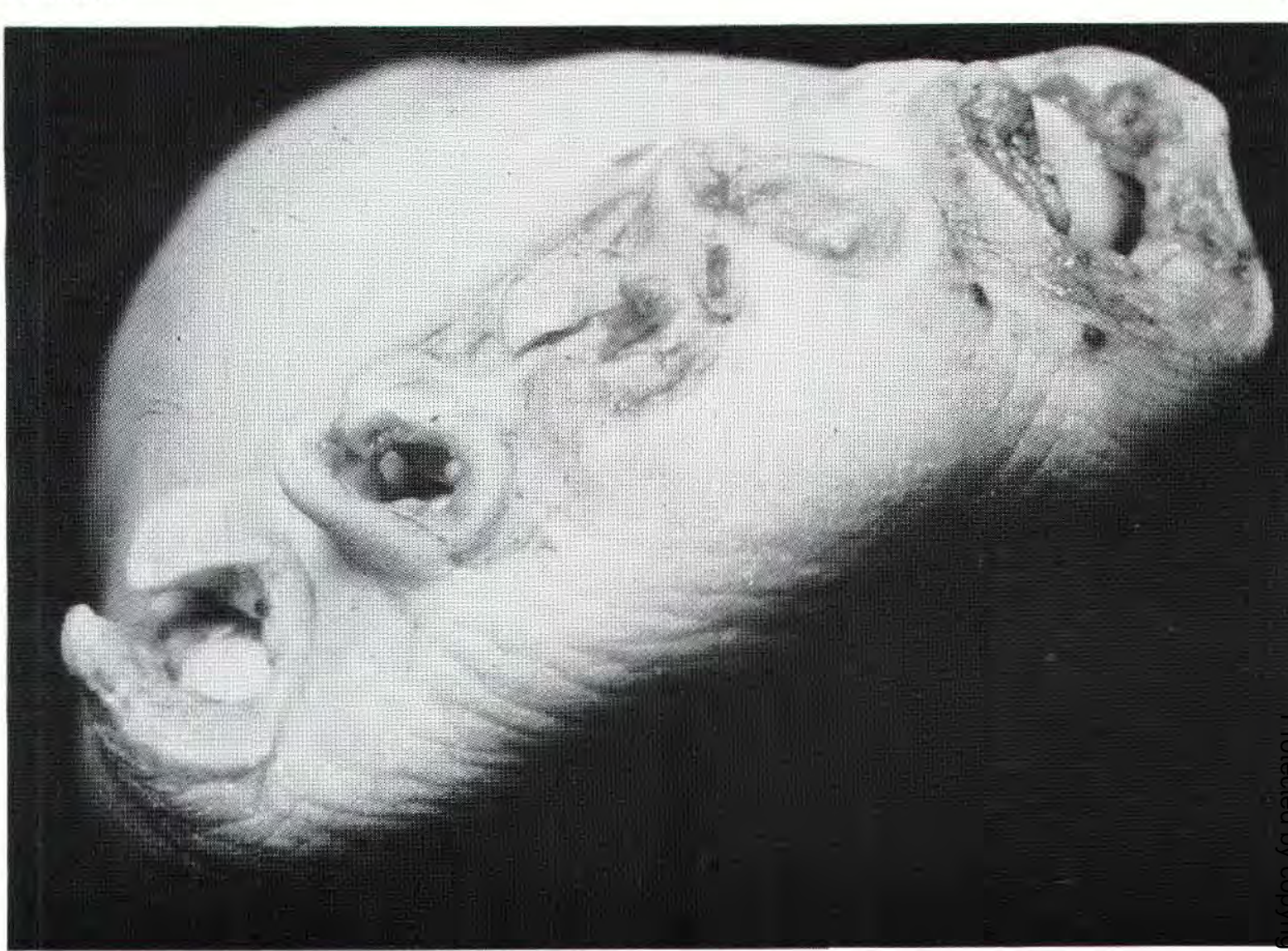

Fig. 3. Right foot post surgery.

1985 , 31 cases of cold injury, including one case of hypothermia, admitted to hospital, were reported to the author. A great increase in the number of cases of cold injury being reported has been noted in recent years. This can only be attributed partly to increased awareness. If this increase is to be halted, medical and non-medical personnel alike will have to remember and practise the basic skills of survival in cold weather. Much experience has been gained in recent times of the hazards of operating in various cold weather conditions, including in the Falklands, ${ }^{1-3}$ Northern Europe or North West Europe. Information on combating the effects of cold is readily available $e^{4-6}$ to all who have responsibility for training. General Midwinter remains an able foe for all but the best prepared.

\section{Acknowledgement}

My thanks are due to Lt Cols R P Craig and Donal O B McCarthy for permitting me to report on their patient.

\section{REFERENCES}

1. Cralr, R P. Military Cold Injury During the War in the Falkland Islands 1982. An Evaluation of Possible Risk Factors. JR Army Med Corps 1984; 130: 97-99.

2. FRANCIS T J R and GoldEN F St C. Non-freezing Colẹ Injury. A Historical Review. JR Nav Med Serv. 1984; 70 134-139.

3. Francis T J R and Golden F St C. Non-freezing Col Injury: the Pathogenesis. JR Nav Med Serv. 1985; 71: 3-80

4. Handbook of Army Health Chap 6 Army Code No 61257

5. Survival against the Elements Army Code No: 70499.

6. A Soldier's Guide to the Prevention of Cold Injury. BAOR Pubn B156. 1985. 